\title{
New Literacies, New Narratives: Impact on a Portuguese Kindergarten
}

\author{
Sónia Pacheco
}

\begin{abstract}
The present article aims to discuss our daily need to read everything that surrounds us and to properly use the information which comes to us from different kinds of media. The country, society, schools and teachers have to keep up with the new roles that children attribute to them in order to meet their needs as they grow up in a digital world. This article seeks to understand how the decisions and government guidelines made today by policy makers have a real impact on the everyday life of a Portuguese kindergarten and in the practices of teachers and their students. I used both interviews with kindergarten teachers and nonparticipant observation of the children's computer activities to collect data. This study concludes that the teachers who were interviewed feel the need for a change, and their educational suggestions show exactly that need to keep up with the interests of children.
\end{abstract}

Keywords: literacies; narratives; digital media; Portuguese; education

\section{Introduction}

Reading and interpreting information and texts has become a requirement in a world full of technology, where every individual is invited to review and act with creativity. The new possibilities of narratives associated with new information and communication technologies have become a reality which requires a more thorough, precocious search for answers. Preschool education in Portugal has been the subject of several studies in different areas, but not nearly enough has been done compared to other levels of education.

I aim to address the pedagogical practice of teachers and the daily routines of kindergarten children, framed in the argument that both the school and the teachers' roles need to be updated in order to meet the increasingly digital and technology-based needs and interests of children from 3 to 6 years old. I will analyze the Portuguese case in terms of recently developed government projects and guidelines and relate them to a case study. 


\section{Theoretical Framework}

\section{Digital Literacy and New Narratives}

The individual's ability to read has become a requirement-not only conventional and socially accepted reading, but also interpretive and comprehensive reading of all the information available. This knowledge and an information-based society requires a change in roles and functions of each individual in this same society. So many resources and social networks gave us the power to educate and guide others, which means that our network actions challenge us and our role as members of society.

According to the Horizon Report (Johnson, Levine, Smith \& Stone, 2010), it is not only the role of the individual that changes, it is also the school's role in preparing its students for real life. Collaborative work is, thus, in demand among students, faculty, departments, schools, communities, and families. According to the report, "Digital media literacy continues its rise in importance as a key skill in every discipline and profession" (Johnson et al., 2010, p. 6). However, it is also seen as a challenge in an economic-based society, and schools are no exception.

Glister (1997) is another recognized expert in digital literacy, mainly due to his dedication to his studies on the concepts of literacy and digital literacy, particularly in regards to hypertext, interactivity, and user ability of Information and Communication Technologies (ICTs) to collect, evaluate and use information. He adds a comprehensive and utilitarian component in the use of ICT.

More recently, Eshet-Alkalay (2004) introduced a broader definition of digital literacy: "Digital literacy involves more than the mere ability to use software or operate a digital device; it includes a large variety of complex cognitive, motor, sociological, and emotional skills, which users need in order to function effectively in digital environments" (p. 93). This is a very important and relevant study that supports the idea that new literacies, both digital and technological, are contributing to the development of increasingly younger readers, and that the environment where young children interact is important to their actions and learnings, considering that children are growing up in a digital world.

The information collected is effective only if the individual has appropriate reading skills which allow them to research, process and understand that information in order to build knowledge. It is in this regard that school plays a crucial role, regardless of the level of education. The report of the Young Children's Use of Popular Culture, Media and New Technologies Study, funded by BBC Worldwide and the Esmée Fairbairn Foundation (Marsh, Brooks, Hughes, Ritchie, Roberts, \& Wright, 2005) stresses that "[a]s educators we need to have a great amount of knowledge on all agendas that will affect a child's future" (p. 59). That is why it is so important to focus on how this works in a Portuguese kindergarten.

The education system, through the roles of the school, teachers, students, and the community, is responsible for promoting dialogue and collective learning based on social mediation, self-reflection, and through the deconstruction and reconstruction of information. It is necessary to actively participate in this 
information- and knowledge-based society, to "have a say" and act critically and creatively, and with everyone's contribution being valued to make them feel part of a society in constant change. Reading has become an essential and a universal right. The new ICTs can help readers to become more competent and critical towards different kinds of texts in different types of media. We may be witnessing a change in the concepts of reading and reader as a result of the introduction of multiple technological supports in our daily lives (Carrington, 2005).

Reading is not limited to a text on paper or the act of decoding words. It covers onscreen reading in its multiple forms, which, at the same time, encourages new readings and the development of new readers from the earliest ages. I am referring to children who, with relative ease and by trial and error, can use a cellular phone, play with consoles, interact with games on television and make use of the multiple tools of a computer to read texts (Levy, 2009). Children's motor flexibility, along with their predisposition to integrate and absorb new messages and information, regardless of the source, allow them to master the computer tools, such as the keyboard or the touchpad. From a very young age, children can transfer information from one particular digital medium to another.

Rachael Levy (2009) refers to a study with children aged 3 to 6 years old which highlights this same ability. Children who did not have access to a computer at home, but used other forms of digital media, managed to apply their knowledge about multimedia texts when confronted with a computer at school.

The learning opportunities that digital literacy may offer to different actors in the educational process are numerous. Schools and teachers must adapt to the new digital age, mobilizing students and taking advantage of all the possibilities for action in the digital age. The acquisition of their native language and the exposure to literacy within the family context can help children develop skills in different areas, and school must accept this consolidated knowledge in order to meet individual needs.

As children become skilled in the use of technology and proficient in both hardware and software handling, they develop strategies to access, read, and interpret texts, computer graphics, and symbols, and to act upon them. They become proactive and competent in digital literacy. The concept of reader is changing, as well as the traditional concept of text. The digital reader has the power to decide what to do with different kinds of texts, while being exposed to a greater number of textual features that involve motion, sounds, colors, words, and pictographic writing. Decoding is not the most relevant aspect for readers in the digital age. New readings and increasingly younger new readers will contribute to the development of the individual's ability to build new narratives with multimedia texts.

Schools need to keep up with textual diversity and the constant transformation of society and its resources by recognizing the diversity of interpretations, readings and technology that we deal with in our daily lives. All these changes require direct, immediate action from all actors in the educational process, and indirectly from policy makers, who have the power to modify practices 
and intensify the educational intention in the promotion of individual contribution to the benefit of the collective in different domains.

Children's skills and knowledge about emergent and digital literacies, about the possibilities of interpretation and construction of digital narratives and yet in the laterality and fine motor skills are later transferred and used in other learning moments in other levels of education, giving them more chances of success in school.

\section{Portugal, Preschool Education and ICTs: A Brief Framework}

In Portugal, the education system is divided into four levels: preschool education, basic education, ${ }^{1}$ secondary education, ${ }^{2}$ and higher education. Preschool education has its own characteristics, such as the fact that it is optional, and it is governed by a guiding document instead of a mandatory class curriculum or program. This guiding document is designated Orientações Curriculares para a Educação Pré-Escolar (Curricular Guidelines for Preschool Education) (Ministério da Educação, 1997). It gives preschool teachers freedom of action regarding the management of the curriculum, teaching options, and the educational opportunities that can be explored in the classroom. Another aspect worth highlighting in this document is the educational intention in the actions, positions and pedagogical practices of preschool teachers, as well as the fact that this document can be used as a common reference for all the teachers at this level of education.

Focusing on the data in the report entitled Perfil do Aluno (Student Profile) 2011-2012 (Direção Geral de Estatísticas da Educação e Ciência e Direção de Serviços de Estatísticas da Educação, 2013), I found that preschool education had an enrollment rate of $89.3 \%$ in 2011-2012, and the gross enrollment rate for the same school year is $90.9 \%$. These figures show that there was a large investment in preschool education in order to cover a greater number of children from 3 to 6 years old. There were more than 18,896 children of 3-5 years old enrolled in preschools. There has been a considerable increase in the scope of this level of education. In 2002-2003, the actual rate of enrollment in preschool was 76.3\%,13\% higher than the numbers of 2011-2012.

Public education continues to demonstrate a greater response among children from 3 to 6 years old, with 135,130 children enrolled, versus 78,067 children in private schools that depend on state funds and 44,317 in independent private schools.

\footnotetext{
${ }^{1} 1$ st to 9 th grade. Basic education is divided into 3 cycles: 1st cycle from the 1 st grade to the 4 th grade, 2nd cycle from the 5th grade to the 6th grade and 3rd cycle from the 7th grade to the 9th grade.

2 10th to 12 th grade.
} 


\section{ICT Projects in Portugal}

Several projects have been developed over the years in Portugal in order to place the country among the most technologically developed countries in the European Union. The MINERVA (Meios Informáticos no Ensino Racionalização, Valorização e Actualização - Computer Resources in Education Rationalization, Recovery and Update) project was one of the first to be developed, between 1985 and 1994. Funded by the Ministry of Education and Science, it aimed to create new courses within the education system, introduce research projects also in the ICT field, introduce the use of ICTs in the classroom context, and create a specialized class in this area, which became part of the study plan for initial teacher training and helped design educational software for college students. The Faculty of Science and Technology of the New University of Lisbon had a leading role in this matter.

The Nónio-Séc. XXI program lasted from October 1996 to 2002. This program included such projects as Ciência Viva and Internet@Escolas. It was also divided into four subprograms, which included the implementation and development of ICTs in classrooms, IT training, the creation and development of educational software, and the dissemination of information and international cooperation.

Several other important projects were created between 1985 and 2002, which translated into greater investment and awareness by the government regarding the information and knowledge-based societies of Portugal and Europe. The Law of the Education System of 1986, the integration of Portugal in the European Union in the same year, the establishment of the Fundação para a Comunicação Cientifica Nacional (Foundation for National Scientific Communication - FCCN) a year later, the Missão para a Sociedade de Informação (Mission for the Information Society) in 1996, ENIS (European Network of Innovative Schools) three years later, and the Action Plan-Learning at the Information Society were some of these projects.

On January 18, 2001, Decree-Law 6/2001 approved the basic education curriculum reform, regulating and cementing the changes and actions previously developed. This legislation promotes changes to the core competencies of the national curriculum for basic education by defining citizenship education, good knowledge of the Portuguese language, civics, and ICT training as transdisciplinary training.

The Unidade para o Desenvolvimento das TIC na Educação (Unit for the Development of ICT in Education) (EduTIC), was established in 2005 by Order No. 7072/2005. This unit continued the activities initiated by the Nónio Séc. XXI program with the intent to coordinate the network of Competence Centers, revitalize the ENIS schools network, implement Portal da Educação (Education Portal) and work with European Schoolnet.

The Equipa de Missão Computadores, Redes e Internet na Escola (Computers, Networks and Internet in Schools Mission Team - CRIE) was created in 2005 along with EduTIC, with the aim of organizing the actions of the Ministry of Education in 
terms of the educational use of ICTs and improve the teaching and learning process in Portuguese schools.

In my study about the evolution of ICT in Portugal throughout the years, I now focus on the year 2007. This was a crucial landmark for the use and implementation of new technologies in education due to the creation of the Plano Tecnológico de Educação (Technology Plan for Education, PTE) (Ministério da Educação, 2007). This plan aimed to reduce the digital divide, equip schools with hardware and technological resources, generalize the use of ICTs in teaching, and make some changes in the teaching and learning processes.

PTE involves several initiatives which target different age groups and levels of education, namely e.escola, e.professor, e.oportunidades and e.escolinha. With the e.escolinha initiative, the Ministry of Education wanted to make sure that all students of the first cycle of basic education had access to ICTs by granting each student a Magalhães personal computer. Records show that more than 470,000 children in this level of education had access to a personal computer with Internet connection. However, this measure was first subject to budget cuts, and then suspended in 2011 by the current government. The State managed to create favorable conditions for the acquisition of equipment and Internet access, thus fostering collaborative networking at all levels of education.

According to the information provided on the PTE site, schools were more complete and equipped with wireless network access in 2010, and also most students had access to laptops. However, the number of computers in schools is still insufficient, and the ones available are becoming obsolete and have slow Internet connection. Similarly, it is becoming urgent to integrate ICTs in all subject areas and invest in training focused on the teaching and learning processes.

In August 2012, the curricular goals for Portuguese, Mathematics, ICT, Visual Education, and Technical Education in basic education were approved by Order No. $10874 / 2012$, Series II. The purpose was to serve as a common reference between the different cycles of the Portuguese education system by promoting interaction between cycles and an articulated construction of contents, which encourage continuity in the teaching and learning processes.

\section{ICTs in Preschool Education}

The implementation of ICTs in preschool education is a challenge. This level of education covers children from 3 to 6 years old, who are not yet familiar with writing or reading conventions. So far, the ICT programs that have been developed at this level of education are still not enough. The PTE did not include any e.iniciativa (e.initiative - my translation) program to purchase Magalhães computers for this age group. It focused only on compulsory education years, which in Portugal begins in the first cycle of basic education. Nevertheless, the biggest challenge lies in the ability to innovate and to improve the quality of education from the earliest ages. 
The use of ICT at this level of education is especially focused on educational purposes. Socialization and cooperation among peers are some of the goals. The learning goals set for preschool education are based on work, preparation, and implementation of several educational opportunities to be developed with children between the ages of 3 and 6 years old. Among other areas, ICT is perceived as a requirement in a society where children deal with all kinds of media from an early age, while interacting with peers and adults.

In the specific case of ICTs, the learning goals were organized according to four areas: Information, Communication, Production, and Safety (Metas de Aprendizagem). The goals set for the Safety item require that children know the rules for the use of different equipment in their activity rooms. They are also supposed to be careful and be responsible for the hardware to which they have access.

The Production item is directly related to the use of different digital tools that involve sounds, texts, or pictures and that allow children to freely express themselves. Information and communication skills reinforce the importance of socialization, sharing, and the use of network communication. This not only strengthens the reciprocity between peers or even schools, but also gives them the possibility to collect, select, and search for information on the World Wide Web. However, after reviewing the literature on national and international technical reports which analyze the use of ICTs in an educational context in Portugal, I came to the conclusion that these reports do not study the use of ICTs in a preschool context.

As an exception, we can refer to the KidSmart program (KidSmart), whose main goal was to "Add value to education through the integration of Information and Communication Technologies (ICT) in the planning and overall organization of the teaching and learning processes in Preschool Education"3 (Ministério da Educação and IBM Portugal, 2008, p. 8). This is an excellent example of the integration of ICTs in a preschool classroom context, as it calls attention to the best practices that have been developed since its implementation in 2003. However, this program targets only the preschools covered by the Territórios Educativos de Intervenção Prioritária (Priority Educational Territories - TEIP) network set by the Ministry of Education and Science, and by some private institutions of social solidarity in underprivileged communities. This fact substantially reduces the number of schools covered by the KidSmart program.

On the national scene, and regarding projects which involve preschool education, there is the Kinderet - Educative Technologies in Kindergarten Context project, which is cofinanced by the European Commission and integrated into the Leonardo da Vinci program. This was a partnership between the School of Education of the Polytechnic Institute of Beja and the University of Cambridge in the

\footnotetext{
${ }^{3}$ Original quote: “Acrescentar valor à educação através da promoção da integração das Tecnologias de Informação e Comunicação (TIC) no planeamento e organização global dos processos de ensino e de aprendizagem da Educação Pré-Escolar.”
} 
United Kingdom between 2002 and 2005. It aimed to analyze and identify the needs within the framework of ICT use in preschool education in order to develop a more suitable model of continuous training adapted to the Portuguese school reality.

Also in connection with the projects and studies carried out in Portugal on the use of ICTs in preschool education and ICT is NetInfância. This project aimed to analyze the studies which focused on the use of ICTs in preschool education and that were developed during a degree in Preschool Education (NetInfancia).

The Relatório de Avaliação (Evaluation Report) - KidSmart Early Learning Program stresses the importance of exchange and interaction between peers or between the user and the equipment or software. The use of ICTs fosters educational opportunities that help the individual to develop cognitive and social skills and to actively build their educational process. According to this report, the investment made by the partnership between the Ministry of Education and IBM Portugal was of great benefit to the education arena. The first partner was responsible for facilitating the technical and didactic training of teachers and the provision of networks by the schools that were covered by the program, whereas it was IBM's duty to provide and install KidSmart workstations (Ministério da Educação \& IBM Portugal, 2008).

\section{Methodology}

The corpus of this study consists of the observation of 25 preschool students (from 3 to 6 years old) attending a kindergarten in the municipality of Lisbon, which owns a KidSmart Early Learning workstation within the protocol between the Ministry of Education and IBM. This school is part of the TEIP network created by the Ministry of Education and Science, which covers underprivileged communities. This kindergarten serves a multicultural community.

The data for this study was collected during nonparticipant direct observations in an educational context, and interviews with preschool teachers. I have not interviewed other stakeholders such as the school's principal, parents, or policy makers. This happened because I needed a strong and focused look at the teachers in their practices, so that I could define their difficulties and their strengths. During the observations I was able to record both verbal and nonverbal interactions between children as they used the computer, and their actions towards the educational software. The interviews with teachers were carried out according to an exploratory script that included several sections, among which stand out sections $\mathrm{C}$ and $\mathrm{H}$ for addressing questions about Interpretation and Digital Narratives and the Portuguese School Scene.

\section{Data Presentation and Discussion}

\section{Teachers and The Concept of Digital Narratives as Promoters of The Use of ICTs}

Based on the content analysis of the interviews, I came to the conclusion that the concept of digital narratives was seen from different plans of action. They are: 
1) A first plan, in which the teacher becomes part of the story with the help of the computer, and 2) a second plan, in which children use the same computer support and additional software to write stories.

3) The next plan-mentioned by interviewee B-situates digital narratives around the use of a certain program which, for its presentation possibilities, is a resource that is, according to her, "flooding our e-mail accounts"4: stories in PowerPoint.

4) Interviewee B also defines the fourth plan: the use of computer support and word processing to create image files with the correspondent's written identification. The files are available for children to play with on a daily basis in their activity time, and may include manual tracing, identifying letters and words, and matching letters with the ones in their names.

Interviewee A states that digital narratives consist of "Us telling the stories through the computer or them [the children] doing it themselves," 5 stressing that these stories can resort to educational software. The teacher criticizes the hardware currently available in the classroom, the KidSmart Workstation, which, according to her, does not allow children to write unless they are playing a game. In this specific case, the KidSmart Workstation had a word processor, math and science games, and the teacher purchased her own Portuguese language games and some more math games.

Interviewee B defines digital narratives as the stories that are provided or built in PowerPoint, stating, "those are stories on the computer ... in PowerPoint."6 The teacher believes that these stories can be an asset in the development of literary skills, but at the same time, that the lack of a Datashow projector is demotivating, as it complements the stories in PowerPoint presentations in a classroom full of small children. She states, "I do not have access to a Datashow projector. There is a computer in the room, but it is an obsolete one and sometimes I have to bring stories on my own USB flash drive and transfer them into the computer for the children, but it is not the same[.]"7

Lack of maintenance and difficulties in the acquisition of new IT resources and hardware is an obstacle that both teachers face. This is a constant problem often mentioned by the teachers who are part of both international (UNESCO, 2002), and national (Carneiro, Queiroz e Melo, Lopes, Lis, \& Xavier de Carvalho, 2010; Paiva, 2002) studies about the use of ICTs in schools.

Interviewee B emphasizes the need to develop strategies in which the use of ICTs is part of children's daily lives and their learning experience. The teacher believes that the use of ICTs is not limited to the viewing of the stories nor to the direct action on the educational software. It also includes activities that have

\footnotetext{
${ }^{4}$ Original quote: "estão a inundar o nosso email".

${ }^{5}$ Original quote: "Nós a contarmos histórias através do computador ou podem ser eles a fazerem".

${ }^{6}$ Original quote: "São as histórias ao nível do computador ... em PowerPoint".

${ }^{7}$ Original quote: "Eu não tenho Datashow tenho computador na sala mas está um bocadinho obsoleto às vezes levo histórias na pen e ponho lá para eles verem mas não é um Datashow”.
} 
become part of the daily routine. As an example of this, the teacher mentions the activities in her classroom, such as the creation of files with images that are identified in written form and that serve not only as a resource in the computer area, but also to name all objects, games, and furniture in the room. For this teacher it is a crucial, natural activity for children to be surrounded by printed text and also be exposed to writing in a natural fashion. This way, the teacher can also respond to their needs, focusing on the students, on their experiences, on what they have already learned, and helping with what they will learn in the future.

Interviewee A states that reading and writing are two areas where children work and invest when they are on the computer. According to the teacher, the children can transfer what they learn with the reading and writing software to the remaining work to develop in other areas in the room. According to this, "children began to seek support to build words on the computer, which they then use daily in the classroom." 8

Accordingly, interviewee $\mathrm{B}$ believes that children use writing and the computer as a complement to consolidate what they learn and clear their doubts. There are image files on the computer and printed images, and children relate those images to the different objects in the room, copy them manually or on the computer, and print copies. Then each child makes a correspondence between the letters that they already know, the words that they have at their disposal, and the letters in their own names.

This same teacher states that her actions and educational intention take into account the development of skills through the use of ICTs in different moments of their routine, and that the ITC-based knowledge that they build daily helps children develop their literary skills. The teacher gives an example of this: "They really like to identify the letters in their names: 'Look teacher! This letter is also in my name!' And I encourage them and say, 'Is that so? Let's read it.' And we make many games with words." 9

Interviewee A states that children develop deeper relationships between peers and reinforce socialization when they are working on the computer. Besides socializing, the teacher emphasizes that the field of mathematics is also one of the most privileged in learning, since children learn math concepts, such as geometric figures or patterns, among others. She also emphasizes that the ease with which children actively perform on mathematical games makes those same lessons fun and effective.

Interviewee B says that she is aware of the necessary skills in a so-called information society: "We really need to keep up with new technology. They [the

\footnotetext{
${ }^{8}$ Original quote: "As crianças começaram a pedir-me apoio para construir letras no computador que depois usam no seu dia a adia na sala".

${ }^{9}$ Original quote: "gostam muito de identificar as letras que fazem com o nome 'Olha professora o meu nome também tem esta letra' e eu depois incentivo e digo 'Ai é então vamos ler' e fazemos muitos jogos com palavras."
} 
children] will have ICTs and will have all these things during their school life, and they have the Magalhães computer in the first cycle."10

The analysis of the interviews conducted for this research allowed me to define the existing technological resources and educational software both in the interviewees' classrooms and as a resource available for the school faculty, as can be seen in Table 1.

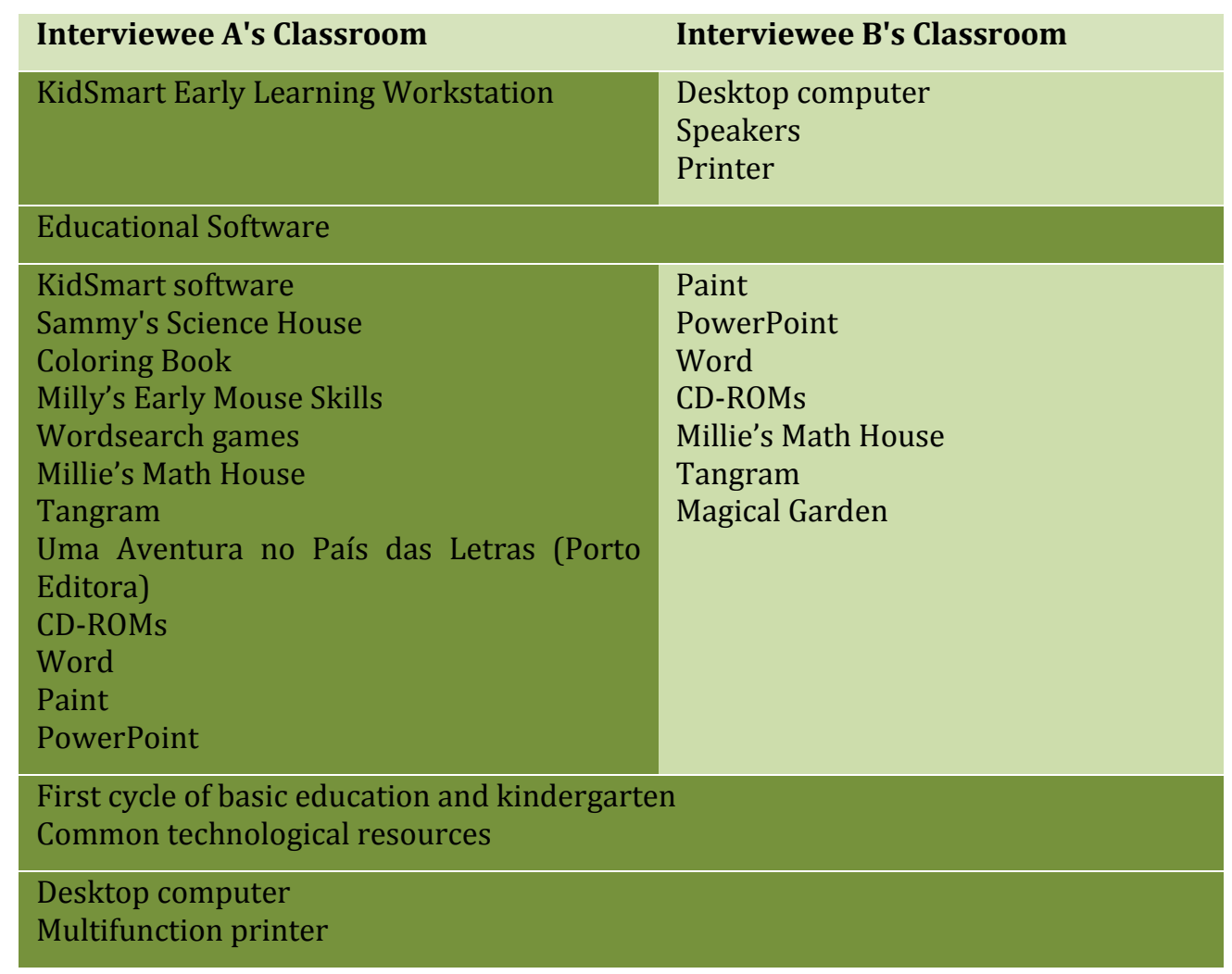

Table 1. Technology Resources/Educational Software in Kindergarten Classrooms

\section{The Use of The Computer}

After interviewing the teachers, it is necessary to observe the way children interact with ICTs. My intention is to analyze the nonparticipant observations in the classroom context in order to understand what the actual use of ICTs in kindergarten is. With a deeper analysis of these observations, I intend to evaluate what children learn from the use of ICTs and how they use that knowledge in other fields of action.

The observations I made allowed me to come to the conclusion that the computer is used on a daily basis, and that it is part of the children's work routine. Classrooms are divided into areas which include the computer. Children are free to choose between the computer area, the writing area, or some other areas in the

\footnotetext{
${ }^{10}$ Original quote: "Temos mesmo de acompanhar estas novas tecnologias eles vão ter as TIC e vão ter durante a escola toda essas coisas e no $1^{\circ}$ ciclo têm o Magalhães.”
} 
classroom. This choice can either be an individual one or it can involve a small group of two to five children. In either case, the teacher respects the children's choices and adopts an attitude of scaffolding towards the students (Vygotsky, 1993). Children resort to educational software mostly for individual or peer work. They play reading and writing, mathematics, science, drawing, or painting games.

Table 2 synthesizes the multiple uses of the computer and software by children and sometimes with the support of the teacher.

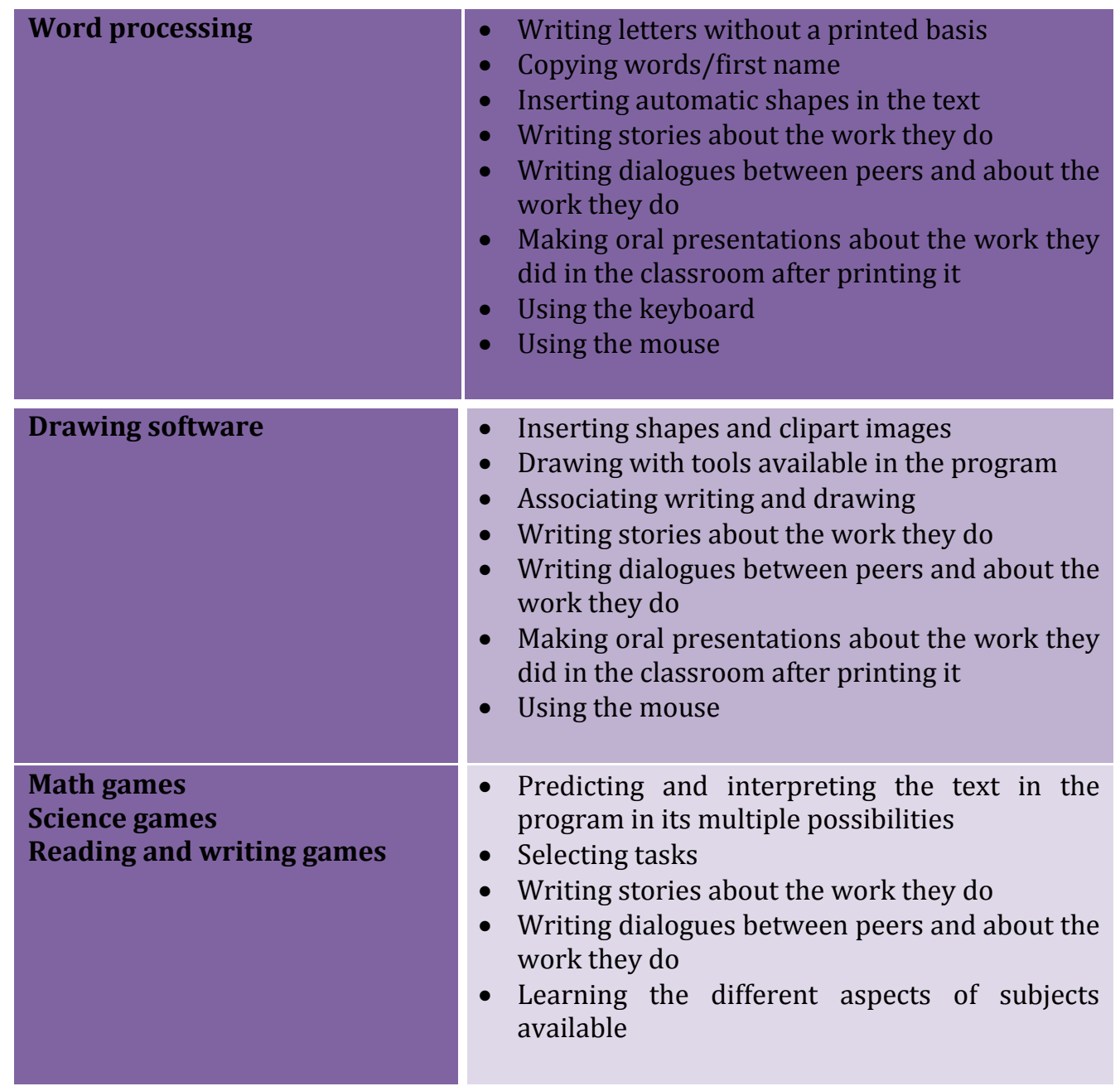

Table 2. Multiple uses of the computer by children

After this compilation of the children's actions, it is important to briefly describe or characterize the different programs that were used during the observations and that the teachers said were frequently used in classroom activities.

\section{Word: word processing}

The location of the toolbar at the top of the screen allows easy viewing, and children can use all the tools that are provided there with relative ease, from changing letters 
to text highlight color or shading. Word is referred to by teachers as a facilitator of creativity, encouraging construction of stories, fantasy, verbal peer interaction, and developing prereading and reading skills.

\section{Paint}

This program is one of the most used in interviewee B's classroom, and its use is immediately facilitated by the program's toolbar and icons. These icons make it easy to predict the text about to be written, since they are very easy to identify and use. Children identify the eraser icon with erasing, the pencil for drawing, the paint bucket that pours color on the different forms in their drawings, the brushes that draw thick and thin lines and that they can use to draw what they want. The letter A is a letter that can be found in their names, and finally, the color palette, which they are constantly changing and taking turns in using it.

The records of the observations show that the use of this program encourages a great variety of verbal interaction, dialogue, creativity, idea association and problem solving among the users.

\section{PowerPoint}

According to interviewee $\mathrm{B}$, this program is used primarily for viewing and reading stories in multimedia text format. She claims to have stories in this format and says that the children read them independently on the classroom computer. At times, these stories are used in group reading, other times the stories are invented by the teacher and children. The only downside to the use of stories in PowerPoint is the lack equipment to project them on a big screen, which creates less impact on the children.

\section{KidSmart software and the "Uma Aventura no País das Letras" program}

This kind of software normally comes with a narrator who interacts with the children and gives them feedback on their decisions and choices. It is the narrator who encourages the children even when they give the wrong answer, stimulating them to try and give the right answer or choose the right path. The children insist on playing until they get the reward for their achievements, which is followed by the sound of "applause" and the verbal positive reinforcement of the narrator.

The programs that are part of the KidSmart Workstation display less written text; the menu is entirely visual, with the addition of sound to vocalize the name of the game and the movements of the narrator. Children have easy access to the multiple features of the program through icons that they easily recognize and read, and a reward system that encourages them to progress. Based on the observations, the presence of motion, sounds, and colors encourages them to move forward and create a relationship with the intermediary/narrator.

Children have fun, laugh, talk with their peers about the intermediary/narrator's comments, and keep playing. An example of this was recorded during one of the observations in Interviewee A's classroom, when a child 
showed their satisfaction with the successful completion of the tasks: "Look! I'm playing very well! I'm doing so many things"11 (Child L).

During the observations, I could identify two areas with records of important and relevant learnings in the children's development, as well as in the active construction of individual and collective knowledge. Those areas are socialization and educational learning integrated in the areas of development.

With regard to socialization, children who use digital media in a classroom context learn to wait their turn to use the computer and mouse; to share relevant information in order to get successful results when playing games or in the completion of tasks; to ask their peers with whom they share digital and technological moments for help (when using the equipment itself, selecting software, or even interpreting a multimedia text with its different icons); to exchange questions and sometimes to go through situations of failure together. These situations do not make children feel frustrated. On the contrary, they encourage brainstorming with peers to achieve success in the task that they are performing. I found that children use trial and error to achieve success, and they define a competitive goal with themselves during the different steps or tasks when playing games. In one of the observations, I recorded examples of the kind of peer interaction and strategies mentioned above:

In interviewee A's classroom, two children-a six-year-old girl and a fiveyear-old boy-are working in the computer area. They choose to play Tangram, which requires fitting several geometric shapes into other shapes. They can't see the lines of the shapes which they have to fit into the predefined shape. These two children were already playing this game for some time, always alternating their turns to play without any kind of conflict. Girl $R$ is the leader and boy $U$ the observer-apprentice-actor.

It is boy U's turn to play. He drags the geometric shapes into the predefined shape, but does not succeed in completing his task. Girl R tries to help him by giving suggestions about the steps to complete the task: "Now you click on this one and you put it here." 12 She first points at the shape on the screen with her index finger and drags it to the right place. Given that the boy does not succeed in his task, the girl puts her hand over the boy's hand, holding the mouse and helping him drag the picture to the right place. The boy insists and persists, finally managing to succeed in putting the shape in the right place.

The girl was able to support the boy's performance and he could build knowledge based on their mutual support to succeed in the task and be recognized and appreciated by other members of the group of children and the teacher.

It was possible to pinpoint, based on the observations, various educational lessons with the use of technological equipment and software:

\footnotetext{
${ }^{11}$ Original quote: "Olha eu estou a conseguir fazer muitas coisas".

${ }^{12}$ Original quote: “Agora carregas neste e pões aqui”.
} 


\section{The use of hardware}

laterality; moves back and forth depending on the selected item; interpretation and reading of icons on the computer screen; fine motor skills with mouse manipulation; eye-hand coordination; on and off.

The use of software

1) Proficiency in math: patterns; logical sequence; classification; virtual fitting of shapes; numbers; geometry; naming, identification, and attribution of colors; quantities; sizes; one-to-one correspondence; input to fill in tables.

2) Proficiency in language skills and approach to reading and writing: verbal interactions with the software's narrator/intermediary; verbal interaction with peers; definition and naming the letters of the alphabet; introduction of the user's first name in the game and success achieved (highest scores); fill in the blanks with words; storyteller allows children to hear a story, turn the pages, define the sequence of the story and perform tasks related to the story after listening to it; identifying the letters in their names and in the names of their classmates; creating stories based on tasks and on interaction with peers; associating sounds and letters; relating words to different contexts; copying words and producing invented writing; word exploration; use of the keyboard; understanding and exploring writing and reading features by producing texts that can be printed, combining different kinds of texts, for example, drawing in Paint and adding letters; the audio component of the programs allows children to "play" with words and their sounds, helping them with their pronunciation and correcting any mistakes in verbal language.

3) Knowledge of the world: identification of different kinds of food, everyday objects, actions, landscapes of different seasons of the year and of foreign countries; development of scientific reasoning through hypothesis testing by trial and error throughout the different tasks in the game.

\section{Conclusion}

The analysis of the collected data confirms that the use of ICTs in the preschool context and in the first levels of the educational process helps children develop a range of skills, such as solving problems and making decisions. These skills can be applied in different areas of development and help solidify new knowledge. In addition to these opportunities for personal development, I also saw improvements in educational interventions and intentions which characterize the practices of preschool teachers.

It is also possible to conclude that, over time-focused on the Portuguese scene-there was a greater investment in projects and programs from the first cycle of basic education on. Also, those covering preschool education are more focused on the field of ongoing teacher training and on the assessment of their knowledge, and not on the implementation and use of ICTs in a kindergarten context. However, the KidSmart Early Learning project stands out in this matter, with results in what concerns hardware and software and in the daily use of the workstations available 
in the establishments covered by the protocol between IBM and the Ministry of Education and Science.

Based on the interviews with both teachers, I concluded that they consider peer work to be very important in the computer area. Interacting and sharing equipment help consolidate some social rules and strengthen social skills, such as waiting their turn to play a game, exchanging equipment and doubts, respecting opinions and solving problems together. I noticed that this was a reality in both classrooms, and that there were no conflicts during the time the children were working on the computer.

Despite the two-children limit on working together on the computer imposed by the teachers, the number rarely holds. Several children move closer to where their classmates are, observe them performing their tasks, make suggestions and build narratives, and interpret the texts that are being worked on by the two children who are on the computer.

The children observed in this study show interest and pleasure when interacting with the technological resources and software. It is possible to infer by our observations that the use of hardware in these preschool classrooms is part of the daily routine.

In spite of the difficulties which the two kindergarten teachers defined as being obstacles to the improvement and strengthening of their knowledge in the ICT area, their effort and commitment are clear in the educational opportunities which are promoted in the daily routines of the children.

The teachers have a self-evaluative capacity to define the need to know how to act and how to keep up with the technological evolution in education. They believe that the use of ICT is becoming increasingly more important in the definition of classroom activities, within a range of educational intention and active learning so as to help develop technological and literary skills in preschool children.

Regardless of the difficulties described by the teachers, it appears that children show interest, pleasure, creativity, and critique towards hardware and software. They interpret the texts in their multiple possibilities, put into practice what they learn, build their knowledge, and contribute to the construction of the collective knowledge of both their peers and adults. The teachers are aware of their students' needs, invest time in them and use their own economic resources on training and software, refusing to fall behind in an information society.

In conclusion, there is a real need to invest in the acquisition and installation of diverse educational software and hardware in order to meet the needs of children today. It is also important to form work teams to do maintenance of the computer systems, since they cannot be replaced for newer ones. These computer systems need upgrades and adjustments that require technical knowledge and skills that the teachers do not have. 


\section{References}

Carneiro, R., Queiroz e Melo, R., Lopes, H., Lis, C., \& Xavier de Carvalho, L. (2010). Observatório do Plano Tecnológico da Educação. Lisbon: Gabinete de Estatística e Planeamento da Educação (GEPE), OPTE.

Carrington, V. (2005). New textual landscapes, information and early literacy. In J. Marsh (Ed.), Popular culture, new media and digital literacy in early childhood. Oxford: RoutledgeFalmer.

Direção-Geral de Estatísticas da Educação e Ciência \& Direção de Serviços de Estatísticas da Educação. (2013). Perfil do aluno 2011/2012. Lisbon: DireçãoGeral de Estatísticas da Educação e Ciência.

EduTIC. Retrieved from http://www.edutic.giase.min-edu.pt/

E.escola. Retrieved from http://www.eescola.pt/e-escolinha/oquee.aspx and http://www.eescola.pt/

E.escolinha. Retrieved from http://www.escolinhas.pt

Eshet-Alkalai, Y. (2004). Digital literacy: A conceptual framework for survival skills in the digital era. Journal of Educational Multimedia and Hypermedia, 13(1), 93-106.

Glister, P. (1997). Digital literacy. New York: John Wiley and Sons.

Johnson, L., Levine, A., Smith, R., \& Stone, S. (2010). The 2010 Horizon Report. Austin, TX: The New Media Consortium. Retrieved from http://www.nmc.org/pdf/2010-Horizon-Report.pdf

KidSmart. Retrieved from http://www.kidsmartearlylearning.org

Levy, R. (2009). You have to understand words ... but not read them: Young children becoming readers in a digital age. Journal of Research in Reading, 32(1), 75-91.

Marsh, J., Brooks, G., Hughes, J., Ritchie, L., Roberts, S., \& Wright, K. (2005). Digital beginnings: Young children's use of popular culture, media and new technologies. Sheffield, UK: Literacy Research Centre, University of Sheffield.

Metas de Aprendizagem. As metas na Educação Pré-Escolar. Retrieved from http://metasdeaprendizagem.dge.mec.pt/educacao-preescolar/apresentacao/

Ministério da Educação. (1997). Orientações curriculares para a educação préescolar. Lisboa: Editorial do Ministério da Educação.

Ministério da Educação. (2007). Plano Tecnológico da Educação. (Anexo à Resolução do Conselho de Ministros no 137/2007, de 18 de Setembro). Lisbon: GEPE/ME.

Ministério da Educação \& Companhia IBM Portuguesa. (2008). Relatório de Avaliação - KidSmart Early Learning Program. Lisbon: DGIDC/ERTE/PTE.

NetInfancia. Retrieved from http://netinfancia.blogspot.pt 
Paiva, J. (2002). As tecnologias de informação e comunicação: Utilização pelos professores. Lisbon: Ministério da Educação - DAPP.

PTE (Plano Tecnológico de Educação). Retrieved from http://www.pte.gov.pt/

UNESCO. (2002). Information and communication technologies in teacher education: A planning guide. Paris: UNESCO.

Vygotsky, L.S. (1993). Pensamento e linguagem. São Paulo: Martins Fontes. 